\title{
Surfaces
}

\section{INTRODUCTION TO ALEXANDER GAVRILOV'S "HUMANISM AS ANTI-IDEOLOGY"}

\section{Hazard Adams}

Volume 9, 2001

TROISIÈME CONGRÈS INTERNATIONAL SUR LE DISCOURS

HUMANISTE. LA RÉSISTANCE HUMANISTE AU DOGMATISME AUJOURD'HUI ET À LA FIN DU MOYEN ÂGE

THIRD INTERNATIONAL CONFERENCE ON HUMANISTIC

DISCOURSE. HUMANISTIC RESISTANCE TO DOGMATISM TODAY

AND AT THE END OF THE MIDDLE AGES

URI : https://id.erudit.org/iderudit/1065063ar

DOI : https://doi.org/10.7202/1065063ar

Aller au sommaire du numéro

Éditeur(s)

Les Presses de l’Université de Montréal

ISSN

1188-2492 (imprimé)

1200-5320 (numérique)

Découvrir la revue

Citer ce document

Adams, H. (2001). INTRODUCTION TO ALEXANDER GAVRILOV'S "HUMANISM AS ANTI-IDEOLOGY". Surfaces, 9. https://doi.org/10.7202/1065063ar
Résumé de l'article

Dans le cadre du troisième congrès international sur le discours humaniste, le texte résume l'introduction à « Humanism as Anti-Ideology » de Alexander Gavrilov qu'avait proposée Hazard Adams et rapporte les principaux enjeux qui ont été l'objet de discussions. 


\section{INTRODUCTION TO \\ ALEXANDER GAVRILOV'S \\ «HUMANISM AS ANTI- IDEOLOGY 》}

Hazard Adams

Surfaces vol IX 101.3 (v1.0a - 15.12.2001) - ISSN: 1188-2492

Tout texte reste la propriété de son auteur. Néanmoins, SURFACES demande d'être citée à l'occasion de toute autre publication du texte en question.
ABSTRACT
In the context of the Third International Conference on Humanistic Discourse, this text summarizes the introduction to Alexander Gavrilov's « Humanism as Anti-Ideology » that Hazard Adams delivered and reports on the central concerns that emerged in its discussion.

\section{RÉSUMÉ}
Dans le cadre du troisième congrès international sur le discours humaniste, le texte résume l'introduction à « Humanism as Anti-Ideology » de Alexander Gavrilov qu'avait proposée Hazard Adams et rapporte les principaux enjeux qui ont été l'objet de discussions.

Hazard Adams introduced Alexander K. Gavrilov's paper by remarking that Gavrilov was primarily interested in the relation of humanism to ideology, which he saw as dangerously productive of ideocracy. Humanism he identified with philology, which he regarded as its 
vanguard. His account emphasized the situation of humanism in the communist period in Russia. He held that humanism tended to face two ways: toward philanthropy and toward misanthropy, toward the democratic and toward elitism, toward culture and toward nature, toward religion and toward agnosticism. He held also that humanism's ideas are linked to no doctrine. Ideology becomes ideocracy through the consolidation and exercise of power. In the Russian instance, the human desire for truth was insulted by the attack on the right to know the past. The humanities express the desire to know the past and are grounded on the classics, the relative translatability of which illustrates the basic unity of humankind past and present. Gavrilov posited the notion of a counterideology, usually mechanically opposed to the prevailing ideocracy. This is usually a previously defeated ideology. It can be useful, but he also posits a third, ultimately more effective third, which he identifies by Solzenytsin's phrase "active passive resistance." This third acts slowly by erosion.

Adams remarked that in Gavrilov's discourse humanism is not, ideally at least, ideological and should be identified with the third form, something antithetical to both ideology and counter-ideology. Concentrating his further remarks on Sections III.3 and III.4 of Gavrilov's paper, Adams suggested a revision of Gavrilov's argument. He challenged Gavrilov's view that philology can be entirely free of ideology except by ironic recognition of its own inevitable ideological tendency; but, he observed, too much philological discourse fails to achieve this irony. The third strategy that Gavrilov offered could not, then, be philology but would have to be closer to poetry. Philology, as an interpreter of poetry, is too easily a bowdlerizer or a moral allegorizer and can never escape its own categories, which involve it in the analytical methods of its time. But neither is poetry quite a pure third term (as in Giabattistas Vico's age of giants it would have to have been). Irony would have come when interpretation began or seemed necessary. Poetry's irony, an irony of statement, would be its protection against its own ideological tendency. Philology, condemned cyclically to encounter the irony of its situation, is at best midway between poetry and the dominant ideological discourse of its time.

Adams went on to suggest that a third term such as Gavrilov offered ought not to suppress the dyadic opposition that it opposes, but to reveal that opposition as a fiction, which asa fiction might have some value. He added that a counter-ideology may be necessary to an 
ideology as a scapegoat and therefore oddly complicit with it. He observed further that humanism in the United States has suffered attack by Christian fundamentalists against what they call godless or agnostic "secular humanism." It has also been denigrated by certain postmodernist intellectuals as identical with the rise of the despised epsitemological subject and the political individual. Some of this has rubbed off on the term "humanities" as it is employed in higher education, but for the most part the term in American universities is a bureaucratic one indicating the disciplines that have not yet declared themselves sciences.

\section{Roundtable Discussion}

\section{Summary}

Hazard Adams

Ernst Behler

Hendrik Birus

Jacques Derrida

Alexander Gavrilov

Andreas Kablitz

Murray Krieger

Wolfgang Iser

J. Hillis Miller

Rainer Warning

Alexander Gavrilov proceeded to distinguish between counter-ideology and anti-ideology (his third term) and held that the latter was not ideological but a weapon against ideology. Classical philology was the paradigm in the field of the humanities, bringing forth the spirit of humanism, and this could be seen both from an historical and from a theoretical perspective. Philology was an instrument for the protection and preservation of poetry and was poetry's sister.

Murray Krieger asked whether anti-ideology didn't slip into ideology and wondered whether it had to victimize itself, further whether humanistic discourses might be distinguishable by their functions. Gavrilov observed that the formalists and structuralists broke the hegemony of ideology but didn't have to be completely accepted. Speaking admittedly as a "fierce traditionalist," he saw advantages in that. 
Andreas Kablitz saw humanism as a study of weaknesses and advantages, and Rainer Warning observed that the very term "humanistic discourse" was mythical and the term "humane," required deconstruction. He worried that to refer to the humanities as "authoritative," as Gavrilov had, raised serious questions. He suggested poetry as the proper antidote to ideology. Jacques Derrida reminded the group that Gavrilov's paper should be taken in its particular cultural context, but that other questions arise. For instance, what about the history of the concept of ideology? He had difficulty identifying something as ideology-free, nor is poetry such. What is ideology? Perhaps, he suggested, there are only counter -ideologies. Gavrilov answered that by "ideology" he meant a consciously organized system of doctrine and that philological study is not linked to such ideological structures, though it can be used to ideological purposes, for it is hard to avoid ideology in the humanities. J. Hillis Miller observed that there seemed to be a radical difference in the notion of the humanities, as the group had discussed them, in Chinese and Russian. Likewise between Russia and the United States with respect to the term "ideology," which in Russian seems to mean a conscious promulgation, whereas in the United States it refers to something not necessarily conscious but tacit. He discussed the tacit assumptions about philology current at the Johns Hopkins University when he first taught there. The humanist tradition was always wrapped in an ideological context, the attitude toward poetry included. Ernst Behler added that from Alexandria forward the philological tradition had been ideological. Gavrilov repeated that he had not intended ideology in that sense, and he insisted that philology was necessary to make intellectual beginnings. The different cases of Lotman and Jakobson were offered by Wolfgang Iser and Hendrik Birus respectively. Lotman advanced the humanities via cultural semantics: Discourse shapes awareness, converts entropy into information, beginning with certain assumptions. Gavrilov remarked that Lotman was counter-ideological, having introduced new and often unspoken texts into Russia. He made many good points despite his theory. Philology should use the oldest methods and at the same time be unpredictable and evasive. He spoke against ideological power in the practice of philology, opposing all "schools." Krieger was the last to speak, remarking that Gavrilov's use of the term "ideology" does apply even to the tacit ideology of which Miller spoke. Krieger held out the hope for a discourse - poetry - that tries to free itself by exposing ideology (even its own) to critique. 